\title{
Efficient Treatment of Resistant Orbital Pseudotumor with CyberKnife: Case Series and Short Review of Literature
}

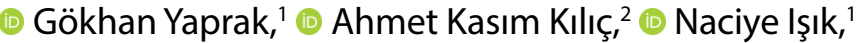 \\ (1) Dilber Çelik Yaprak, ${ }^{3}$ (1) Özgür Ozan Şeşeogulları ${ }^{4}$
}

$$
\begin{aligned}
& \text { Department of Radiation } \\
& \text { Oncology, University of Health } \\
& \text { Sciences, Kartal Dr. Lütfi Kırdar } \\
& \text { Training and Research Hospital, } \\
& \text { Istanbul, Turkey } \\
& \text { 2Department of Neurology, } \\
& \text { University of Health Sciences, } \\
& \text { Kartal Dr. Lütfi Kırdar Training and } \\
& \text { Research Hospital, Istanbul, Turkey } \\
& { }^{3} \text { Department of Ophthalmology, } \\
& \text { Ümraniye Training and Research } \\
& \text { Hospital, İstanbul, Turkey } \\
& { }^{4} \text { Department of Radiation Oncology, } \\
& \text { Medicana International Hospital, } \\
& \text { Biruni University, Istanbul, Turkey } \\
& \text { arys }
\end{aligned}
$$

\begin{abstract}
Orbital inflammatory syndrome (OIS) or orbital pseudotumor is the most frequent cause of an orbital mass. Most cases are steroid responsive, but treatment of patients with refractory OIS may also include radiotherapy. Presently described are 3 cases of orbital pseudotumor that had a partial steroid response or recurrence and were treated successfully with CyberKnife (Accuray Inc., Sunnyvale, CA, USA).
\end{abstract}

\section{INTRODUCTION}

Orbital inflammatory syndrome (OIS)—previously known as idiopathic orbital inflammation, inflammatory orbital pseudotumor, or non-specific orbital inflammationis the most frequent cause of painful orbital masses in adults. ${ }^{[1,2]}$ The OIS incidence is between $4.7 \%$ and $6.3 \%,{ }^{[3,4]}$ and it constitutes about $10 \%$ of orbital mass lesions. ${ }^{[1,2]}$ The etiological factors include thyroid disorders, systemic lupus erythematous, rheumatoid arthritis, IgG4-related disorders, sarcoidosis, and granulomatosis with polyangiitis. ${ }^{[5-8]}$

Pseudotumors are rarely infiltrative. Radiological findings were summarized as infiltration of the retrobulbar fat, enlargement of the extraocular muscles, thickening of the optic nerve/sheath complex, contrast enhancement, and proptosis. ${ }^{[9]}$ Intracranial extension is rare, but it has been documented in up to $8.8 \%$ of patients. ${ }^{[10]}$ Soft-tissue edema, decreased ocular motility, proptosis, decreased visual acuity, or pain can be seen clinically. 
The OIS treatment mainly consists of steroids, and about $80 \%$ of patients are steroid responsive. ${ }^{\left[{ }^{[I]}\right]}$ Also, $33 \%-58 \%$ of patients may have recurrent OIS. ${ }^{[12,13]}$ Patients with refractory OIS can be effectively treated with radiation therapy. ${ }^{[14,15]}$ Here, we present three cases of patients with refractory OIS who were treated with hypofractionated stereotactic radiotherapy (HSRT) with CyberKnife (Accuray Inc., Sunnyvale, CA, USA). We also present a short review of literature.

\section{CASE SERIES}

Case I- A 39-year-old female patient was admitted to a hospital with diplopia occurring by down gaze and swelling on left eyelid for three months. Her biochemical and serological tests were normal. She had no systemic or rheumatologic condition. Her magnetic resonance imaging (MRI) revealed mass lesion located in left superior rectus muscle in left orbital that was compatible with pseudotumor or inflammation. She was given a two-month steroid treatment course with adequate dosing. Despite the steroid regimen, she had partial response, and she was referred to our center for radiotherapy option. After I500 cGy (three fractions) HSRT with CyberKnife, the patient had complete clinical recovery. However, after 12 months of follow-up, repeat MRI showed partial regression.

Case 2-A 17-year-old male patient complained of swelling of left eyelid, and MRI showed a mass that invades superior oblique and superior rectus muscles in the left orbit. Lesion has shown very dense enhancing that was compatible with orbital pseudotumor. There was no rheumatological or neoplastic finding in his diagnostic tests. He was also given the steroid treatment. After two months of steroid treatment, there was no evident regression of lesion. Therefore, he was evaluated for radiotherapy. 2000 cGy radiotherapy 10 fraction protocol was applied to left orbit. After three months of follow-up, left-sided mass lesion showed complete resolution. Four months from the last visit, onset of new symptom was observed in the right eye. MRI showed $45 \times 29 \mathrm{~mm}$ sized lesion compatible with pseudotumor. After the complete failure of two-month steroid regimen, 800 cGy radiotherapy with CyberKnife was applied to the right orbit as a single fraction. Recurrence was obtained at the seven-month control visit. Reirradiation was given as 10 fraction with a total dose of 2000 cGy. Regression was achieved after second radiotherapeutic approach.

Case 3- A 62-year-old female patient was admitted with right orbital swelling. Her MRI showed mass lesion of pseudotumor (Fig. I). She had no past medical history. Oral steroid treatment was started, but due to treatment resistance, radiotherapy was planned. After 1500 cGy HSRT (three fractions) with CyberKnife (Fig. 2), lesion showed full recovery (Fig. 3). After about a 12 month of follow-up, no recurrence was obtained.

\section{DISCUSSION}

OIS or orbital pseudotumor represents the most frequent cause of orbital masses. ${ }^{[1,2]}$ Most of the patients have monophasic disease course, but some of the patients can show recurrence. ${ }^{[16]}$ In a study performed in 153 non-specific orbital inflammation with a single or multiple recurrences showed that younger age, bilateral disease, partial initial steroid response increased risk of recurrence. ${ }^{[16]}$ Additionally, there may be some risk factors precipitating
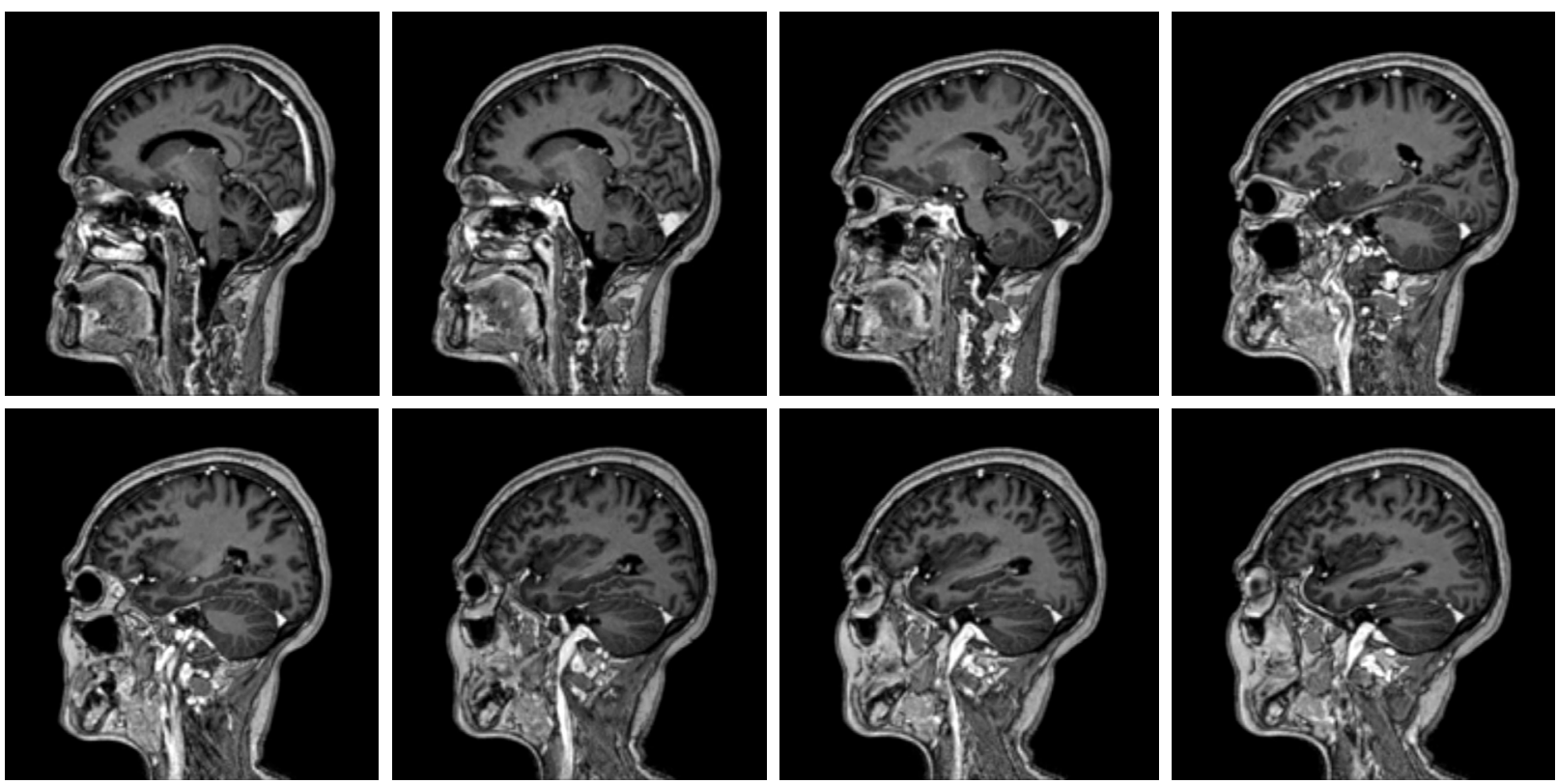

Figure 1. T1-weighted sagittal magnetic resonance images before CyberKnife treatment that shows lesion surrounding right orbit. 


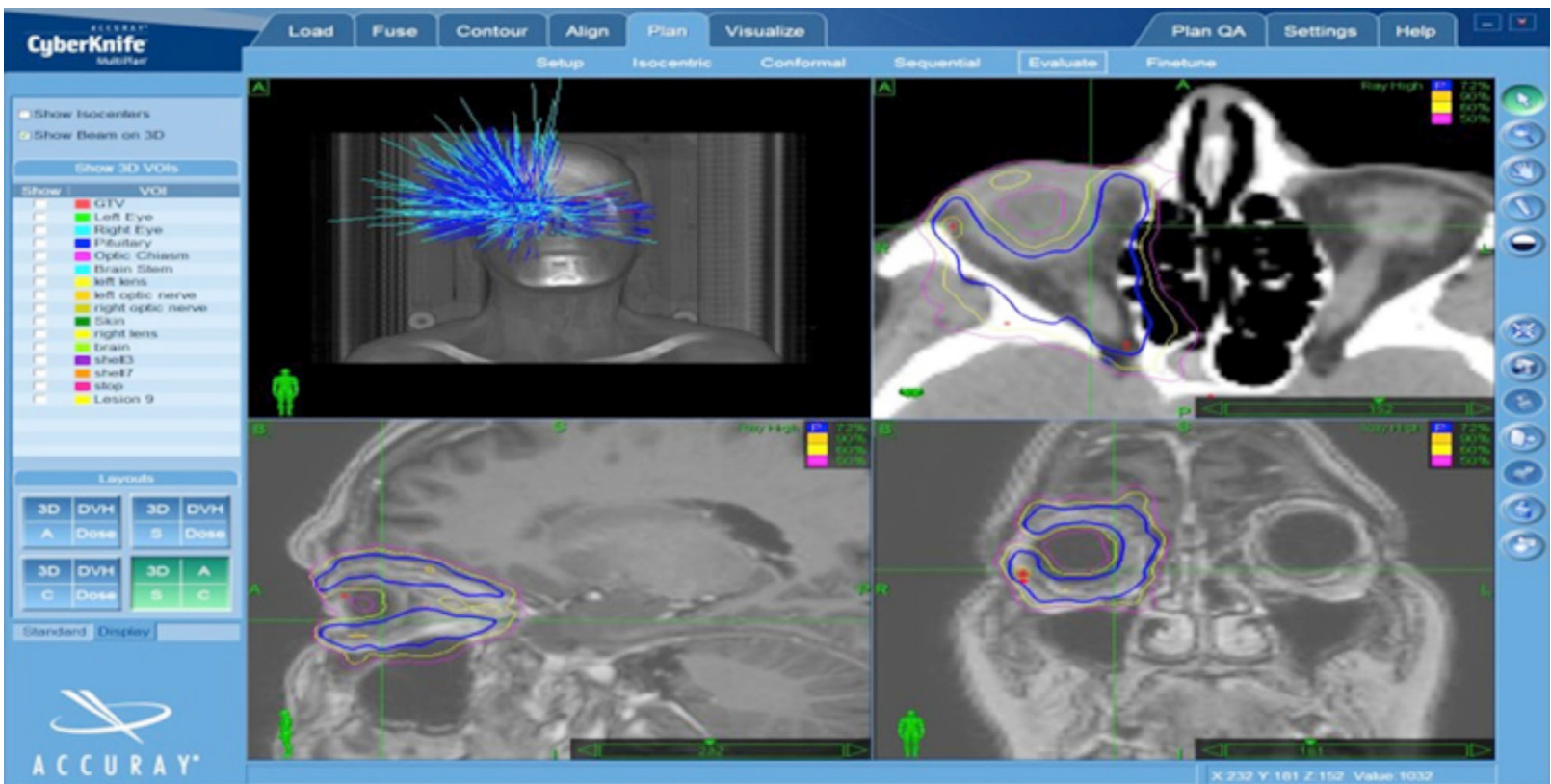

Figure 2. CyberKnife treatment plan of lesion for radiosurgery was shown.

the disease recurrence in the presence of infection ${ }^{[17,18]}$ and autoimmune disease. ${ }^{[19,20]}$ Also, obesity, pregnancy, and bisphosphonate use may also cause disease recurrence. ${ }^{[20]}$ In our case series, a patient showed disease recurrence despite the lack of presented risk factors except onset of young age.

Corticosteroids are usually preferred as the first-line treatment option. Dose of $80 \mathrm{mg} /$ day for I week followed by tapering oral dose of prednisone is generally considered as the first-line treatment. ${ }^{[21]}$ Most of the lesions were resolved under steroid treatment. ${ }^{\left[{ }^{I I}\right]}$ In a small number of patient group, low dose of cyclosporine alone or with the combination of prednisone has achieved to stabilize disease course in I or 2 years of treatment. ${ }^{[22]}$ Methotrexate was successfully used in a group of non-infectious orbital inflammatory disease as a long-term therapy. ${ }^{[23]}$ Adalimumab as a TNF- $\alpha$ blocker was able to control disease activity in two steroid dependent and treatment refractory patients. ${ }^{[24]}$

Local therapy at doses between 20Gy and 30Gy is generally reserved for patients who fail to respond to medical treatments. These consisted of radiation therapy at
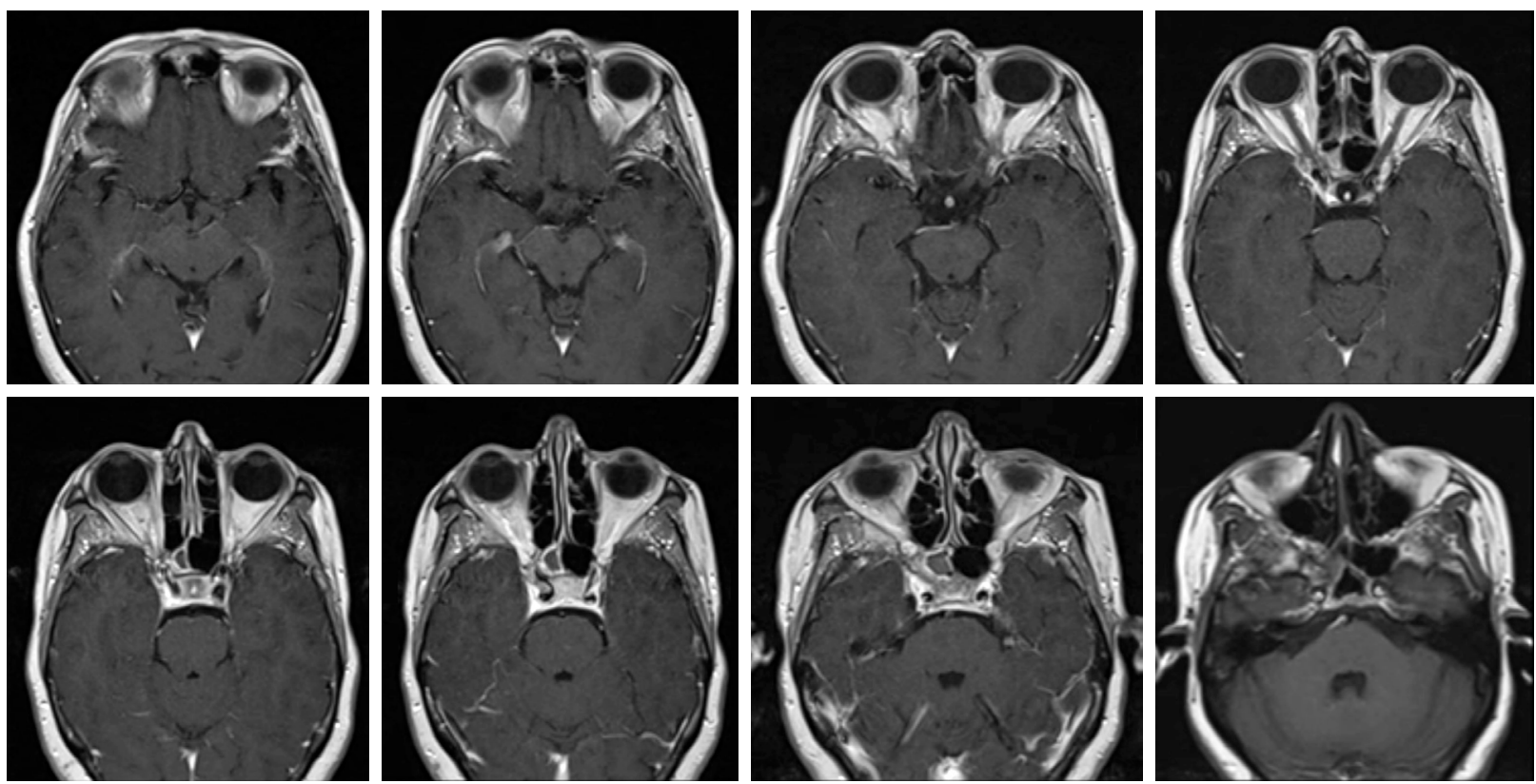

Figure 3. Axial T1-weighted Gd scans after radiation therapy. Lesion regressed after treatment. 
conventional fractionation. ${ }^{[25]}$ In refractory course or in the situation of pharmacologic treatment side effects or contraindications, radiotherapy may be considered as a treatment option. In a study consisting of 16 patients, 15 started with corticosteroids. ${ }^{[15]}$ Eight patients had disease recurrence, and one had progression. ${ }^{[15]}$ External-beam radiotherapy was applied to 14 patients. ${ }^{[15]}$ Thirteen patients showed prominent improvement, but the rest of three patients could not have long-term control. ${ }^{\left[{ }^{[5]}\right.}$ Another study with 20 patients revealed that 17 of the treatment group responded to radiotherapy. ${ }^{\left[{ }^{[1]}\right]}$ Among responders, seven cases had partial recovery without an increase of steroid dose, one had complete response with a steroid dose reduction, and nine had complete response without steroid use. $^{[14]}$

HSRT with frameless stereotactic radiosurgery system provides a better optic apparatus protection and a short treatment time (3-5 fractions). In our cases, HSRT was effective, and it was safely used for treatment of orbital pseudotumor.

\section{CONCLUSION}

As a result, besides the steroids, chemotherapeutic agents or monoclonal antibodies radiotherapy seems to be an efficient treatment option.

\section{Informed Consent}

Written informed consent was obtained from the patient for the publication of the case report and the accompanying images.

Peer-review

Internally peer-re viewed.

Authorship Contributions

Concept: G.Y, A.K.K; Design: N.I, G.Y; Data collection \&/ or processing: G.Y, D.Ç.Y; Analysis and/or interpretation: A.K.K, N.I ; Literature search: Ö.O.Ş, N.I.; Writing: A.K.K., G.Y; Critical review: D.Ç.Y, Ö.Ö.Ş.

Conflict of Interest

None declared.

\section{REFERENCES}

1. Shikishima K, Kawai K, Kitahara K. Pathological evaluation of orbital tumours in Japan: analysis of a large case series and 1379 cases reported in the Japanese literature. Clin Exp Ophthalmol 2006;34:239-44. [CrossRef]

2. Shields JA, Bakewell B, Augsburger JJ, Flanagan JC. Classification and incidence of space-occupying lesions of the orbit. A survey of 645 biopsies. Arch Ophthalmol 1984;102:1606-11. [CrossRef]

3. Szabo B, Szabo I, Crişan D, Stefănuț C. Idiopathic orbital inflammatory pseudotumor: case report and review of the literature. Rom J Morphol Embryol 2011;52:927-30.

4. Ding ZX, Lip G, Chong V. Idiopathic orbital pseudotumour. Clin
Radiol 2011;66:886-92. [CrossRef]

5. Espinoza GM. Orbital inflammatory pseudotumors: etiology, differential diagnosis, and management. Curr Rheumatol Rep 2010;12:443-47. [CrossRef]

6. Min HK, Lee YS, Yang SW, Lee J, Kwok SK, Ju JH, Kim WU, Park SH. Clinical outcomes and pathological characteristics of immunoglobulin G4-related ophthalmic disease versus orbital inflammatory pseudotumor. Korean J Intern Med 2017 Oct 19 [Epub ahead of print], doi: 10.3904/kjim.2016.304. [CrossRef]

7. Leo M, Maggi F, Dottore GR, Casini G, Mazzetti P, Pistello M, et al. Graves' orbitopathy, idiopathic orbital inflammatory pseudotumor and Epstein-Barr virus infection: a serological and molecular study. J Endocrinol Invest 2017;40:499-503. [CrossRef]

8. Fernández-Codina A, Pinilla B, Pinal-Fernández I, López C, FraileRodríguez G, Fonseca-Aizpuru E, et al; Spanish Registry of IgG4 Related Disease (REERIGG4) investigators; Autoimmune Diseases Group (GEAS); Spanish Internal Medicine Society (SEMI). Treatment and outcomes in patients with IgG4-related disease using the IgG4 responder index. Joint Bone Spine 2018. pii: S1297. 319X(18)30017-4.

9. Flanders AE, Mafee MF, Rao VM, Choi KH. CT characteristics of orbital pseudotumors and other orbital inflammatory processes. J Comput Assist Tomogr 1989;13:40-7. [CrossRef]

10. Clifton AG, Borgstein RL, Moseley IF, Kendall BE, Shaw PJ. Intracranial extension of orbital pseudotumour. Clin Radiol 1992;45:23-6.

11. Mendenhall WM, Lessner AM. Orbital pseudotumor. Am J Clin Oncol 2010;33:304-6.

12. Swamy BN, McCluskey P, Nemet A, Crouch R, Martin P, Benger R, et al.Idiopathic orbital inflammatory syndrome: clinical features and treatment outcomes. Br J Ophthalmol 2007;91:1667-70. [CrossRef]

13. Yuen SJ, Rubin PA. Idiopathic orbital inflammation: distribution, clinical features, and treatment outcome. Arch Ophthalmol 2003;121:491-9. [CrossRef]

14. Prabhu RS, Kandula S, Liebman L, Wojno TH, Hayek B, Hall WA, et al. Association of clinical response and long-term outcome among patients with biopsied orbital pseudotumor receiving modern radiation therapy. Int J Radiat Oncol Biol Phys 2013;85:643-9. [CrossRef]

15. Matthiesen C, Bogardus C Jr, Thompson JS, Farris B, Hildebrand L, Wilkes B, Syzek E, Algan O, Ahmad S, Herman T. The efficacy of radiotherapy in the treatment of orbital pseudotumor. Int J Radiat Oncol Biol Phys 2017;79:1496-502. [CrossRef]

16. Braich PS, Kuriakose RK, Khokhar NS, Donaldson JC, McCulley TJ. Factors associated with multiple recurrences of nonspecificorbital inflammation aka orbital pseudotumor Int Ophthalmol 2018;38:1485-95. [CrossRef]

17. Casteels I, De Bleecker C, Demaerel P, Van Wilderode W, Missotten L, Wilms G, et al. Orbital myositis following an upper respiratory tract infection: contribution of high resolution CT and MRI. J Belge Radiol 74:45-7.

18. Nieto JC, Kim N, Lucarelli MJ. Dacryoadenitis and orbital myositis associated with lyme disease. Arch Ophthalmol 2008;126:1165-6.

19. McCarthy JM, White VA, Harris G, Simons KB, Kennerdell J, Rootman J. Idiopathic sclerosing inflammation of the orbit: immunohistologic analysis and comparison with retroperitoneal fibrosis. Mod Pathol 1993:6:581-7.

20. Bijlsma WR, van Gils CH, Paridaens D, Mourits MP, Kalmann R. Risk factors for idiopathic orbital inflammation: a case-control study. 
Br J Ophthalmol 2011;95:360-4. [CrossRef]

21. Mombaerts I, Schlingemann RO, Goldschmeding R, Koornneef L. Are systemic corticosteroids useful in the management of orbital pseudotumors? Ophthalmology 1996;103:521-8. [CrossRef]

22. Bielory L, Frohman LP. Low-dose cyclosporine therapy of granulomatous optic neuropathy and orbitopathy. Ophthalmology 1991;98:1732-6. [CrossRef]
23. Smith JR, Rosenbaum JT. A role for methotrexate in the management of non-infectious orbital inflammatory disease. $\mathrm{Br} \mathrm{J}$ Ophthalmol 2001;85:1220-4. [CrossRef]

24. Adams AB, Kazim M, Lehman TJ. Treatment of orbital myositis with adalimumab (Humira). J Rheumatol 2005;32:1374-5.

25. Notter M, Kern T, Forrer A, Meister F, Schwegler N. Radiotherapy of pseudotumor orbitae. Front Radiat Ther Oncol 1997;30:180-91.

\section{Dirençli Orbital Psödo Tümörün CyberKnife Etkin Tedavisi: Olgu Serisi ve Literatürün Kısa Gözden Geçirilmesi}

Orbital enflamatuvar sendrom veya orbital psödotümör orbital kitlelerin en sık nedenidir. Olguların çoğu steroid yanıtlıdır ancak tedaviye dirençli hastalar radyoterapi seçeneğine sahip olabilirler. Burada başarılı bir CyberKnife tedavisi yaklaşımı ile kısmi steroid cevabı veya nüks gösteren üç orbital psödotümör olgusu sunduk.

Anahtar Sözcükler: CyberKnife; orbital psödo tümör; radyoterapi. 